\title{
Chemical, spectroscopic characterization, molecular modeling and antibacterial activity assays of a silver (I) complex with succinic acid
}

José Alberto Paris Junior ${ }^{1}{ }^{\infty}$, Ana Júlia Salvador Rocchi ${ }^{2}{ }^{\oplus}$, Bruno Torquato Biagioni ${ }^{1}{ }^{\oplus}$, Maurício Cavicchioli $^{3+}{ }^{\oplus}$, Rachel Temperani Amaral Machado ${ }^{4}{ }^{\oplus}$, Fernando Rogério Pavan ${ }^{4}$, Pedro Paulo Corbi $^{5} \oplus$, Wilton Rogério Lustri ${ }^{1}{ }^{\oplus}$, Douglas Henrique Pereira ${ }^{6}{ }^{\oplus}$, Antonio Carlos Massabni ${ }^{1,3}{ }^{\oplus}$

1. University of Araraquara, Graduate Program in Biotechnology in Regenerative Medicine and Medicinal Chemistry, Araraquara, Brazil.

2. University of Araraquara, Medicine Course, Araraquara, Brazil.

3. São Paulo State University, Institute of Chemistry, Araraquara, Brazil.

4. São Paulo State University, School of Pharmaceutical Sciences, Araraquara, Brazil.

5. University of Campinas, Institute of Chemistry, Campinas, Brazil.

6. Federal University of Tocantins, Chemistry Collegiate, Gurupi, Brazil.

+Corresponding author: Maurício Cavicchioli, Phone: +55 (16) 3301-9768, Email address: mauriciocavicchioli@gmail.com

\section{ARTICLE INFO}

Article history:

Received: August 05, 2020

Accepted: December 24, 2020

Published: April 01, 2021

\section{Keywords}

1. Silver complex

2. Succinic acid

3. DFT

4. Antibacterial activity

5. Mycobacterium tuberculosis

\begin{abstract}
A silver(I) complex with succinic acid in the form of succinate is presented. Chemical characterization confirms the molecular composition $\mathrm{Ag}_{2} \mathrm{C}_{4} \mathrm{H}_{4} \mathrm{O}_{4}$ for the complex. Infrared spectra suggest a bidentate coordination of both carboxylate groups of succinates to the two $\operatorname{Ag}(\mathrm{I})$ ions. Density functional theory (DFT) studies were used in the structures of succinic acid and $\operatorname{Ag}(\mathrm{I})$ succinate complex with coordination formula $\left[\mathrm{Ag}_{2}\left(\mathrm{C}_{4} \mathrm{H}_{4} \mathrm{O}_{4}\right)\right]$ in order to optimize them to their
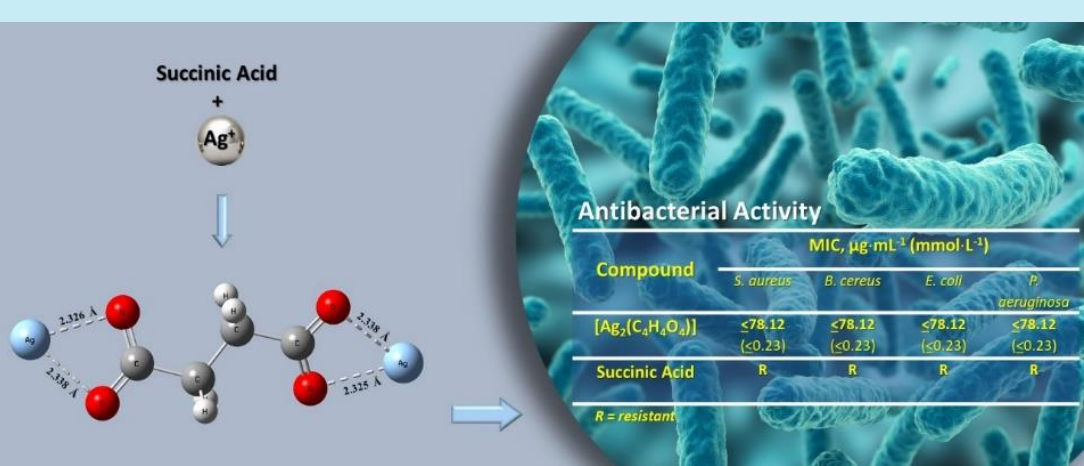
minimum energy. The studies confirmed that each carboxylate group of the succinate anion is coordinated to one silver atom by the two oxygen in a bidentate mode and the bond lengths $\mathrm{O} \cdots \mathrm{Ag}$ theoretically determined range from 2.325 to $2.338 \AA$. The complex $\left[\mathrm{Ag}_{2}\left(\mathrm{C}_{4} \mathrm{H}_{4} \mathrm{O}_{4}\right)\right]$ showed in vitro antibacterial activity against the bacterial strains of Staphylococcus aureus, Bacillus cereus, Escherichia coli and Pseudomonas aeruginosa complex. Anti-Mycobacterium tuberculosis analyses were also performed and the $\left[\mathrm{Ag}_{2}\left(\mathrm{C}_{4} \mathrm{H}_{4} \mathrm{O}_{4}\right)\right]$ complex was shown to be active over M. tuberculosis $\mathrm{H}_{37} \mathrm{Rv}$ strain with $\mathrm{MIC}_{90}$ of $23.94 \mu \mathrm{g} \mathrm{mL}{ }^{-1}$ while succinic acid itself showed a value higher than $25.00 \mu \mathrm{g} \mathrm{mL}^{-1}$.
\end{abstract}




\section{Introduction}

According to recent reviews ${ }^{1,2}$, the bacterial antibiotic resistance is increasing at an alarming rate. The indiscriminate use of antibiotics is largely responsible for the occurrence of resistant bacteria.

One of the most common bacterial strains is Escherichia coli, which is usually found in intestines of warm-blooded organisms. Most strains of E. coli are harmless, but some can cause severe food poisoning. It is transmitted to humans mostly by the ingestion of contaminated foods, such as raw meat, milk and vegetables. Escherichia coli can cause neurological complications (seizures, stroke and coma) in about $25 \%$ of patients with hemolytic uremic syndrome and chronic kidney sequelae in about $50 \%$ of survivors. The E. coli resistance to the standard antibiotic treatment with fluoroquinolones is now widespread. In some countries, this treatment has shown to be ineffective in more than $50 \%$ of patients ${ }^{3}$.

There has been a great increase in resistance to firstline drugs to treat infections caused by Staphylococcus aureus. People infected with $S$. aureus resistant to methicillin are estimated to be $64 \%$ more likely to die than people infected with a nonresistant strain of the same bacteria ${ }^{3}$.

Tuberculosis (TB) is a disease responsible for more than 1.6 million deaths annually and remains a remarkable public health case of concern worldwide. The number of infections is growing up in developed countries, especially for immunosuppressed patients (such as people with diabetes and HIV/AIDS), individuals receiving antitumor therapy and diabetic individuals ${ }^{4}$. Despite the improvement of TB treatment, it is greatly affected by growth of resistant strains of Mycobacterium tuberculosis $^{5}$. In 2017, a range of 483,000-639,000 people worldwide developed TB resistant to rifampicin, the most effective first-line drug, according to the World Health Organization Tuberculosis Report ${ }^{4}$. More alarming is that, within this group, $82 \%$ developed multidrug-resistant $\mathrm{TB}^{6}$. Therefore, the challenge is the search for new substances with antimicrobial activities with a remarkable effectiveness when tested against bacteria (mainly the resistant strains), compared to those drugs used nowadays.
A well-known strategy to obtain active compounds against bacteria includes preparation and uses of silver(I) complexes and Ag nanoparticles. Silver(I) is known for its antimicrobial activities for a long time in medicine and materials sciences ${ }^{7-12}$. The $\operatorname{Ag}(\mathrm{I})$ sulfadiazine complex, for example, has been clinically used as antibacterial and antifungal drug for more than 50 years. This complex is an insoluble compound which slowly liberates $\operatorname{Ag}(\mathrm{I})$ ions when used as a cream to treat bacterial infections in severe burns ${ }^{8}$.

Silver(I) ions interact with DNA ${ }^{13}$ or with S-donor ligands in vital enzymes and inactivate them ${ }^{14,15}$. Consequently, there is an increase of pyrimidine dimerization by a photodynamic process and interruption of DNA replication. So, $\mathrm{Ag}(\mathrm{I})$ complexes with $\mathrm{N}$ - and $\mathrm{O}$-donor ligands have increased ability to replace such molecules by the S-donor ligands of target bacterial proteins ${ }^{10,16,17}$.

Succinic acid (Fig. 1) is a nonhygroscopic acidulant of relatively low acid strength largely used in food and beverage industries. It is also a precursor to produce some polyesters and a component of alkyd resins heavily used in automotive and electronics industries ${ }^{18}$. The ligand is very well studied and has no toxicity or mutagenicity. So, if the complex is to be applied in vivo in the future, safety on the ligand is ensured. Furthermore, succinic acid has a chemical structure with two carboxylate groups, which are particularly good coordination points to prepare metal complexes. Succinic acid is an intermediate metabolic of the Krebs cycle. So, it could be expected that this characteristic promotes a higher intracellular absorption of the complex when compared to $\mathrm{AgNO}_{3}$ and $\mathrm{Ag}(\mathrm{I})$ complexed to other ligands reported in the literature.

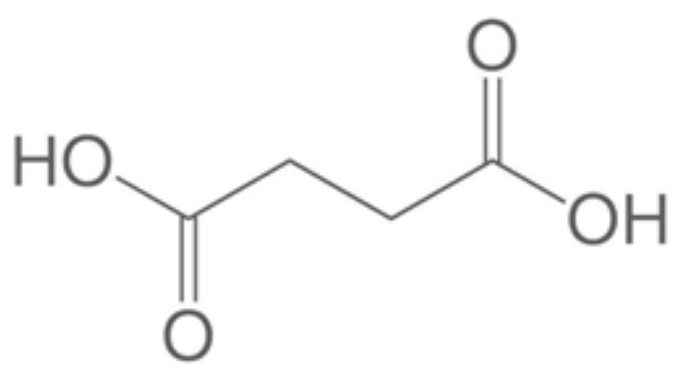

Figure 1. Chemical structure of succinic acid. 
Succinic acid complexes have already been described in the literature, such as the interaction of neodymium(III) and iron(III) with it and some of its derivatives ${ }^{19}$. Sladkov et al. ${ }^{20}$ studied complexation of uranyl $\left(\mathrm{UO}_{2}\right)$ and plutonyl $\left(\mathrm{PuO}_{2}\right)$ with succinic acid in aqueous acid solutions.

In the present work, synthesis and characterization combining experimental and density functional theory (DFT) studies of an $\mathrm{Ag}(\mathrm{I})$ complex with succinic acid in the form of succinate are described. Antibacterial assays of the complex against the Gram-positive bacteria Staphylococcus aureus ATCC 25923 and Bacillus cereus ATCC 14579 and the Gram-negative Escherichia coli ATCC 25922 and Pseudomonas aeruginosa ATCC 27853 were also performed and are described in this manuscript.

\section{Experimental}

\subsection{Materials}

Succinic acid and silver nitrate were analytical grade chemical products from Sigma/Aldrich laboratories. All other chemicals were purchased from different sources. The reagents were used as received.

\subsection{Synthesis}

An aqueous solution $(20 \mathrm{~mL})$ with $3.0 \mathrm{mmol}$ of succinic acid was adjusted to $\mathrm{pH} 7.0$ with $\mathrm{KOH} ; 20 \mathrm{~mL}$ of another aqueous solution containing $6.0 \mathrm{mmol}$ of $\mathrm{Ag}(\mathrm{I})$ nitrate was added under stirring to the succinic solution in a dark room. A white precipitate was immediately formed. The solid was collected by filtration and left to dry in a desiccator with $\mathrm{P}_{4} \mathrm{O}_{10}$ protected from light. Anal. Calc. for $\left[\mathrm{Ag}_{2}\left(\mathrm{C}_{4} \mathrm{H}_{4} \mathrm{O}_{4}\right)\right]$ (\%) C 14.5, H 1.2. Found (\%) C 14.6, H 1.0. Yield: $75 \%$.

\subsection{Instrumental methods}

Carbon, hydrogen and nitrogen $(\mathrm{CHN})$ elemental analyses were performed using a CHNS-O 2400 series II (Perkin Elmer) analyzer. Infrared (IR) spectra were obtained on a FTIR Cary 630 Agilent spectrophotometer, equipped with attenuated total reflectance (ATR) sampling apparatus. The resolution was set at $4 \mathrm{~cm}^{-1}$. Thermal analyses were performed on a thermoanalyzer TG/DTA simultaneous SDT Q-600 (TA Instruments) under the following conditions: aluminum crucible, synthetic air $\left(100 \mathrm{~mL} \mathrm{~min}^{-1}\right)$, heating rate of $10{ }^{\circ} \mathrm{C}$ per min and temperature range from 30 to $1000{ }^{\circ} \mathrm{C}$.

\subsection{Computational simulations}

All the methods described in this section were based in previous work ${ }^{21}$. The chemical structures of succinic acid and the $\mathrm{Ag}(\mathrm{I})$ succinate complex $\left[\mathrm{Ag}_{2}\left(\mathrm{C}_{4} \mathrm{H}_{4} \mathrm{O}_{4}\right)\right]$ were optimized to the minimum of energy by the application of DFT with B3LYP ${ }^{22-24}$. The basis sets 6$31+\mathrm{G}(\mathrm{d}, \mathrm{p})^{25-27}$ were applied for carbon $(\mathrm{C})$, hydrogen $(\mathrm{H})$ and oxygen $(\mathrm{O})$ atoms. The LANL2DZ ${ }^{28}$ effective core potential basis set was used for $\mathrm{Ag}$ atoms. Frequency calculations were employed to confirm that the optimized structures were at their minimum energy and no imaginary frequencies were found. Gaussian program 09 was used to perform all the calculations ${ }^{29}$. Gauss View 5.09 program was used to generate some structures ${ }^{30}$.

\subsection{Determination of the minimal inhibitory concentration (MIC)}

Determination of the minimum inhibitory concentration (MIC) of the free ligand and $\left[\mathrm{Ag}_{2}\left(\mathrm{C}_{4} \mathrm{H}_{4} \mathrm{O}_{4}\right)\right]$ was performed using different reference bacterial strains, S. aureus ATCC 25923, B. cereus ATCC 14579, E. coli ATCC 25922 and P. aeruginosa ATCC 27853, as described in CLSI 2016 ${ }^{31,32}$. The bacterial strains were inoculated in tubes containing $10.0 \mathrm{~mL}$ of brain heart infusion (BHI KASVI) and incubated for $18 \mathrm{~h}$ at $35-37{ }^{\circ} \mathrm{C}$. Sufficient inoculums of each bacterial suspension were added in new tubes of sterile BHI medium until reaching 1.0 turbidity of the McFarland nephelometric scale $(\sim 3.0 \times$

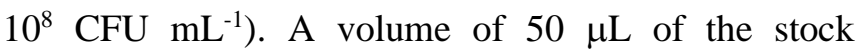
solution $\left(20 \mathrm{mg} \mathrm{mL} \mathrm{m}^{-1}\right)$ of the free ligand and $\left[\mathrm{Ag}_{2}\left(\mathrm{C}_{4} \mathrm{H}_{4} \mathrm{O}_{4}\right)\right]$ suspended in $20 \%$ dimethyl sulfoxide (DMSO) aqueous solution were added from the second well (B) of the 96-well microplate plus $50 \mu \mathrm{L}$ of sterile 
BHI medium, followed by serial dilutions (5.0 to $0.078 \mathrm{mg} \mathrm{mL}^{-1}$ ) and $100 \mu \mathrm{L}$ of the microorganism suspensions, on the McFarland 1.0 scale, were added to each well, reaching turbidity 0.5 McFarland $\left(\sim 1.5 \times 10^{8} \mathrm{CFU} \mathrm{mL}^{-1}\right)$ in a final volume of $200 \mu \mathrm{L}$ well ${ }^{-1}$. In the first well of the microplate, used as a growth control, $50 \mu \mathrm{L}$ of sterile BHI medium, 50 $\mu \mathrm{L}$ of $20 \%$ aqueous DMSO solution and $100 \mu \mathrm{L}$ of bacterial suspensions were added, on scale 1.0 McFarland. The microplates were incubated for $18 \mathrm{~h}$ at $35-37{ }^{\circ} \mathrm{C}$ in a humid chamber under agitation at 150 rpm. After the incubation period, $15 \mu \mathrm{L}$ of $0.02 \%$ resazurin in sterile aqueous solution was added to each hole in the plates. After $3 \mathrm{~h}$ of reincubation, the reading was performed. When active (or able to replicate), the bacterial cells convert the "blue" resazurin to "pink" resorufin. The lower concentration that resulted in the inhibition of bacterial growth (or blocked the conversion of resazurin to resorufin) was considered the MIC value. The tests were performed in triplicate.

\subsection{Anti-Mycobacterium tuberculosis analyses}

The $\mathrm{MIC}_{90}$ of compounds against the standard $M$. tuberculosis $\mathrm{H}_{37} \mathrm{Rv}$ strain was determined with resazurin microtiter assay (REMA). Briefly, the compounds were dissolved in Middlebrook 7H9 broth, oleic albumin dextrose catalase (OADC) and glycerol $0.5 \%$. The solutions of the compounds, in a range concentration of 0.09 to $25 \mathrm{mg} \mathrm{mL}^{-1}$, were placed in a microplate (96-well) containing the bacterial inoculum,

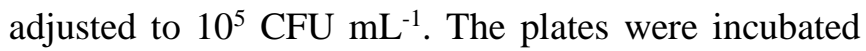
for seven days at $37{ }^{\circ} \mathrm{C}, 5.0 \% \mathrm{CO}_{2}$ atmosphere. An aqueous solution of resazurin $(0.01 \%)$ was added and the fluorescence was read at $530 / 590 \mathrm{~nm}$ after incubation of $24 \mathrm{~h}$. The $\mathrm{MIC}_{90}$ is the lowest concentration of the compound, which inhibits $90 \%$ of bacterial growth ${ }^{33}$. Three replicates were performed.

\section{Results and discussion}

\subsection{IR spectra}

Some bands of the IR spectrum of the complex change significantly when compared to the succinic acid and its potassium salt indicating coordination of succinate to the metal by the carboxylate group. Figure 2 shows the IR spectra of succinic acid, $\mathrm{K}^{+}$-succinate (the anionic form of succinic acid) and the $\left[\mathrm{Ag}_{2}\left(\mathrm{C}_{4} \mathrm{H}_{4} \mathrm{O}_{4}\right)\right]$ complex. The spectrum of succinic acid shows a very large stretching $\mathrm{O}-\mathrm{H}$ band in the range 3300-2500 $\mathrm{cm}^{-1}$. It also shows a combined absorption pattern in the range $3300-2500 \mathrm{~cm}^{-1}$, with a broad $\mathrm{O}-\mathrm{H}$ band superimposed on the sharp stretching bands of $\mathrm{C}-\mathrm{H}$. The reason for a so broad $\mathrm{O}-\mathrm{H}$ stretching band of succinic acid is certainly because carboxylic acids usually exist as hydrogen-bonded dimers. This band disappears in the spectra of both potassium salt and complex. The second change is in the stretching and bending vibrations $\mathrm{C}=\mathrm{O}, \mathrm{C}-\mathrm{O}$ and $\mathrm{O}-\mathrm{H}$ in the region $1300-1700 \mathrm{~cm}^{-1}$. The $\mathrm{C}=\mathrm{O}$ stretching mode of succinic acid occurs at $1675 \mathrm{~cm}^{-1}$, the $\mathrm{O}-\mathrm{H}$ bend at 1408 and $890 \mathrm{~cm}^{-1}$ and the $\mathrm{C}-\mathrm{O}$ stretch at $1304 \mathrm{~cm}^{-1}$. For $\mathrm{K}^{+}$-succinate, the $\mathrm{COO}^{-}$ions generate a strong asymmetric stretching vibration $\left(\mathrm{vCOO}^{-}{ }_{a s}\right)$ at $1559 \mathrm{~cm}^{-1}$ and a weak symmetric stretching vibration $\left(\mathrm{vCOO}^{-}{ }_{\text {sym }}\right)$ at $1392 \mathrm{~cm}^{-1}$. These bands are located at $1507 \mathrm{~cm}^{-1}\left(\mathrm{vCOO}_{a s}^{-}\right)$and at $1385 \mathrm{~cm}^{-1}\left(\mathrm{vCOO}^{-}\right.$sym $)$in the silver-succinate complex. The difference between $\mathrm{vCOO}^{-}$as and $\mathrm{vCOO}^{-}$sym $(\Delta v)$ depends on the type of coordination between the metal and the carboxylate. The carboxylate group keeps the $\mathrm{C}_{2}$ symmetry when coordinating as a bridging or a bidentate group. The metal atom is equally associated with the two oxygen atoms in the succinate salt. The difference $\Delta v$ between the $\mathrm{COO}^{-}$asymmetric and symmetric stretching frequencies in the carboxylate salt and in the complex is 167 and $122 \mathrm{~cm}^{-1}$, respectively, suggesting a bidentate coordination of each carboxylate group to the two $\operatorname{Ag}(\mathrm{I})$ ions $^{34,35}$.

The structure of succinate molecule is highly symmetric. So, the IR bands of the two carboxylate groups would have the same frequencies and such bands are superimposed. Consequently, $\Delta v$ should be the same for both carboxylate groups. In summary, each carboxylate group is coordinated to one $\mathrm{Ag}(\mathrm{I})$ ion in a bidentate mode. 


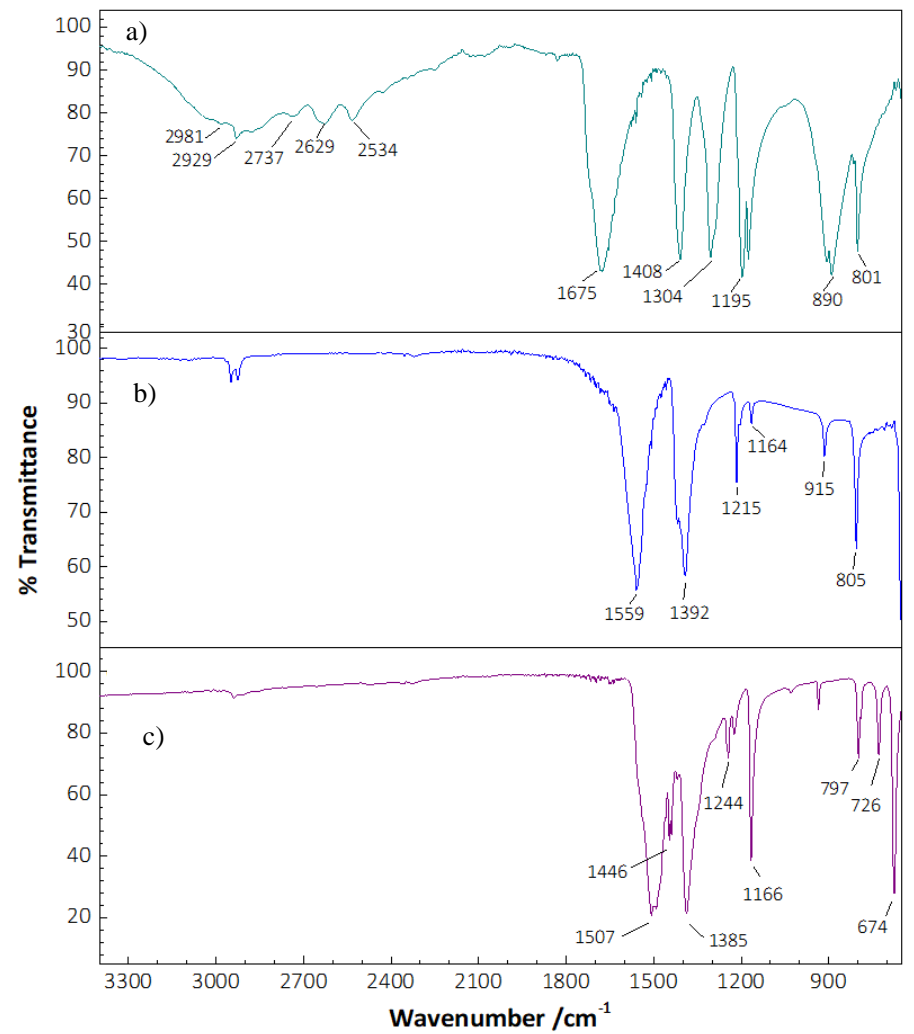

Figure 2. Infrared spectra of succinic acid (a), potassium succinate (b) and $\left[\mathrm{Ag}_{2}\left(\mathrm{C}_{4} \mathrm{H}_{4} \mathrm{O}_{4}\right)\right]$ (c).

\subsection{Thermogravimetric measurements}

Figure 3 shows the thermogravimetric curve for the $\left[\mathrm{Ag}_{2}\left(\mathrm{C}_{4} \mathrm{H}_{4} \mathrm{O}_{4}\right)\right]$ complex, with only one well-defined mass loss. The loss of about $34 \%$ occurred in the range $260-310{ }^{\circ} \mathrm{C}$ and corresponds to the net mass loss. The final residue percentage is in accordance with the formation of metallic silver. Differential scanning calorimetry (DSC) analysis of $\left[\mathrm{Ag}_{2}\left(\mathrm{C}_{4} \mathrm{H}_{4} \mathrm{O}_{4}\right)\right]$ (Fig. 4) shows the occurrence of only one exothermic event at $304{ }^{\circ} \mathrm{C}$, which corresponds to oxidation of the ligand leading to the formation of the residue of $\mathrm{Ag}^{0}$.

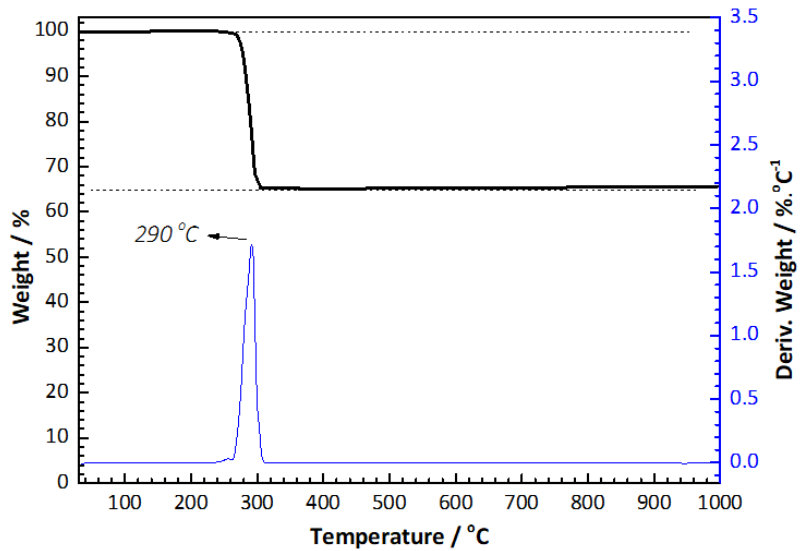

Figure 3. Thermogravimetric curves (TG and DTG) for $\left[\mathrm{Ag}_{2}\left(\mathrm{C}_{4} \mathrm{H}_{4} \mathrm{O}_{4}\right)\right]$.

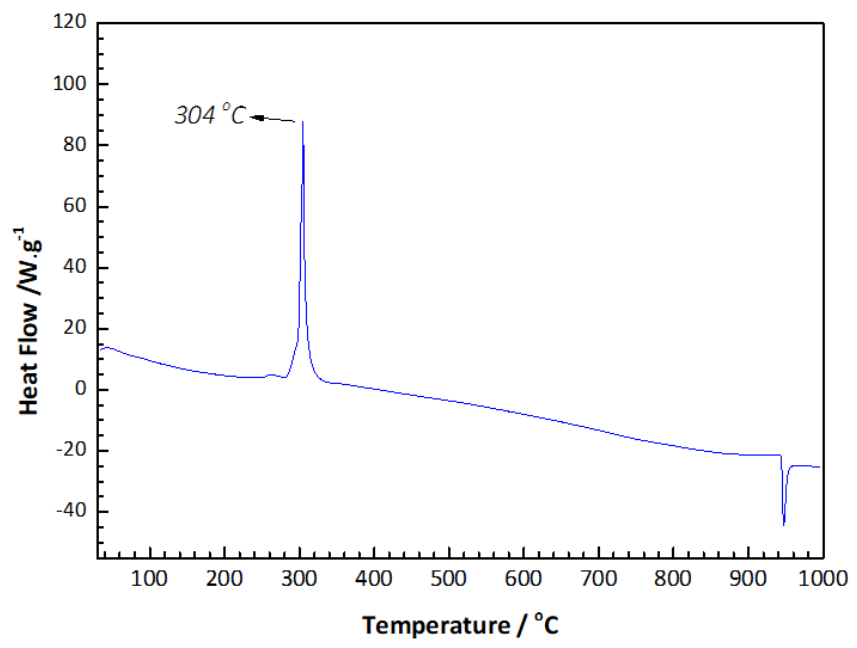

Figure 4. Differential scanning calorimetry (DSC) for $\left[\mathrm{Ag}_{2}\left(\mathrm{C}_{4} \mathrm{H}_{4} \mathrm{O}_{4}\right)\right]$.

\subsection{Electronic and structural properties by density functional theory (DFT)}

Succinic acid and $\left[\mathrm{Ag}_{2}\left(\mathrm{C}_{4} \mathrm{H}_{4} \mathrm{O}_{4}\right)\right]$ were theoretically studied and their structural parameters after complexation and their frontier molecular orbitals (FMO) were determined. The structural parameters calculated were the bond lengths for the metal and oxygen (O‥Ag) (Fig. 5). 


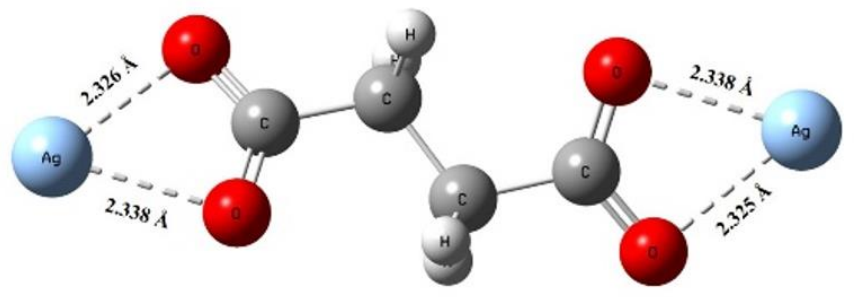

Figure 5. Structural formula for $\left[\mathrm{Ag}_{2}\left(\mathrm{C}_{4} \mathrm{H}_{4} \mathrm{O}_{4}\right)\right]$ and the bond length values for the $\mathrm{O} \cdots \mathrm{Ag}$ bonds.

By analyzing the results, it is possible to observe that each carboxylate group of the succinate coordinates to one $\mathrm{Ag}$ atom by the two $\mathrm{O}$ atoms in a bidentate mode and the theoretically determined bond lengths $\mathrm{O} \cdots \mathrm{Ag}$ were in the range from 2.325 to $2.338 \AA$. It is important to note that, for optimization, the $\mathrm{Ag}$ atom was placed close to the $\mathrm{O}$ atom and no imaginary frequencies were identified after optimization, showing that the structure determined in Fig. 6 was at minimum energy. The theoretically determined values for the $\mathrm{O} \cdots \mathrm{Ag}$ bond are similar to the crystal data found in the literature for a silver complex with mixed ligands 2-aminobenzonitrile and 4-methylbenzoic acid, where the carboxylate group is coordinated to silver in a bidentate chelate mode ${ }^{36}$. The frontier molecular orbitals highest occupied molecular orbital (HOMO), lowest unoccupied molecular orbital (LUMO) and the energy gap for succinic acid and the $\left[\mathrm{Ag}_{2}\left(\mathrm{C}_{4} \mathrm{H}_{4} \mathrm{O}_{4}\right)\right]$ complex were evaluated and are also shown in Fig. 6.

The results indicate that the HOMO and LUMO orbitals of succinic acid, as well as the HOMO of $\left[\mathrm{Ag}_{2}\left(\mathrm{C}_{4} \mathrm{H}_{4} \mathrm{O}_{4}\right)\right]$ are located over all molecular structures. The exception was the LUMO of the complex which is most located over the $\mathrm{Ag}$ atoms. The results for the determined energy gap were
$\Delta \mathrm{E}=7.21 \mathrm{eV}$ for the ligand and $\Delta \mathrm{E}=3.32 \mathrm{eV}$ for the complex. The values of gap show that there is a significant decrease in the energy gap $(\cong 3.89 \mathrm{eV})$ after complexation, which indicates that the complex is more reactive than the ligand.
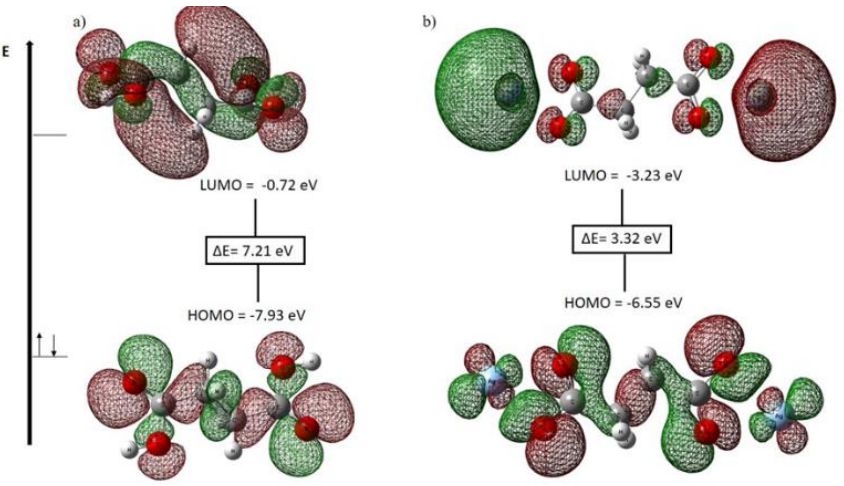

Figure 6. Frontier molecular orbitals and energy gap for: a) succinic acid and b) $\left[\mathrm{Ag}_{2}\left(\mathrm{C}_{4} \mathrm{H}_{4} \mathrm{O}_{4}\right)\right]$ complex.

\subsection{Minimum inhibitory concentration (MIC)}

The $\left[\mathrm{Ag}_{2}\right.$ (succ) $]$ shows its inhibitory activity against Gram-positive and Gram-negative bacteria used in the assay. The free ligand succ and DMSO aqueous solution did not show antibacterial activities. The results are summarized in Table 1.

The results suggest that antibacterial activity of $\left[\mathrm{Ag}_{2}\left(\mathrm{C}_{4} \mathrm{H}_{4} \mathrm{O}_{4}\right)\right]$ is due to the release of $\mathrm{Ag}^{+}$ions in the same way it was described for $\mathrm{Ag}$-sulfadiazine and for other $\mathrm{Ag}$ complexes. Inhibition (in $\mathrm{mmol} \cdot \mathrm{L}^{-1}$ ) provided by $\left[\mathrm{Ag}_{2}\left(\mathrm{C}_{4} \mathrm{H}_{4} \mathrm{O}_{4}\right)\right]$ was higher than that observed by the starting salt $\mathrm{AgNO}_{3}$. It is already described in the literature that $\mathrm{Ag}^{+}$can link to the cell membrane and consequently inhibits cell divisions. Silver ions also binds to bacterial DNA and RNA and inhibits bacterial replication ${ }^{37}$.

Table 1. Minimum inhibitory concentration (MIC) values of $\mathrm{AgNO}_{3}$, succinic acid and $\left[\mathrm{Ag}_{2}(\mathrm{succ})\right]$.

\begin{tabular}{|c|c|c|c|c|c|c|c|c|}
\hline & \multicolumn{2}{|c|}{$\begin{array}{c}\text { S. aureus } \\
\text { ATCC } 25923\end{array}$} & \multicolumn{2}{|c|}{$\begin{array}{c}\text { B. cereus } \\
\text { ATCC } 14579\end{array}$} & \multicolumn{2}{|c|}{$\begin{array}{c}\text { E. coli } \\
\text { ATCC } 25922\end{array}$} & \multicolumn{2}{|c|}{$\begin{array}{l}\text { P. aeruginosa } \\
\text { ATCC } 27853\end{array}$} \\
\hline & $\begin{array}{c}\mathrm{MIC} \\
\mu \mathrm{g} \cdot \mathrm{mL}^{-1}\end{array}$ & $\begin{array}{c}\mathrm{MIC} \\
\mathrm{mmol} \cdot \mathrm{L}^{-1}\end{array}$ & $\begin{array}{c}\mathrm{MIC} \\
\mu \mathrm{g} \cdot \mathrm{mL}^{-1}\end{array}$ & $\begin{array}{c}\mathrm{MIC} \\
\mathrm{mmol} \cdot \mathrm{L}^{-1}\end{array}$ & $\begin{array}{c}\mathrm{MIC} \\
\mu \mathrm{g} \cdot \mathrm{mL}^{-1}\end{array}$ & $\begin{array}{c}\mathrm{MIC} \\
\mathrm{mmol} \cdot \mathrm{L}^{-1}\end{array}$ & $\begin{array}{c}\mathrm{MIC} \\
\mu \mathrm{g} \cdot \mathrm{mL}^{-1}\end{array}$ & $\begin{array}{c}\mathrm{MIC} \\
\mathrm{mmol} \cdot \mathrm{L}^{-1}\end{array}$ \\
\hline$\left[\mathrm{Ag}_{2}(\operatorname{succ})\right]$ & $\leq 78.12$ & $\leq 0.23$ & $\leq 78.12$ & $\leq 0.23$ & $\leq 78.12$ & $\leq 0.23$ & $\leq 78.12$ & $\leq 0.23$ \\
\hline Succinic acid & $\mathrm{R}$ & & $\mathrm{R}$ & & $\mathrm{R}$ & & $\mathrm{R}$ & \\
\hline $\mathrm{AgNO}_{3}$ & $\leq 78.12$ & $\leq 0.45$ & $\leq 78.12$ & $\leq 0.45$ & $\leq 78.12$ & $\leq 0.45$ & $\leq 78.12$ & $\leq 0.45$ \\
\hline
\end{tabular}

$\mathrm{R}=$ Resistant. Student t-test was used to determine the statistical significance for $S$. aureus, B. cereus, E. coli and P. aeruginosa replicates. Results were expressed as the mean $(* * * \mathrm{p}<0.005)$. 
So, the use of silver complex promotes a slower release of the silver ions when compared to silver nitrate. This characteristic increases the antibacterial effect of the compound. For example, the role of silver and sulfadiazine in the mechanism of action of silver sulfadiazine on burn wound infections was investigated ${ }^{38}$. The efficacy of silver sulfadiazine is thought to result from its slow and steady reactions with serum and other sodium chloride-containing body fluids, which permits the slow and sustained delivery of silver ions into the wound environment. In this circumstance, a relatively minimum amount of sulfadiazine appears to be active.

Furthermore, the ligand succinic acid is an intermediate metabolic of the Krebs cycle. So, it is suggested that this characteristic promotes a higher intracellular absorption of the complex when compared to $\mathrm{AgNO}_{3}$ and $\mathrm{Ag}(\mathrm{I})$ complexed to other ligands reported in the literature.

The results obtained in this work demonstrated that the $\left[\mathrm{Ag}_{2}\left(\mathrm{C}_{4} \mathrm{H}_{4} \mathrm{O}_{4}\right)\right]$ complex showed significant growth inhibition activity of the tested bacterial species, when compared with other studies that report the inhibitory activity of bacterial growth by $\operatorname{Ag}(\mathrm{I})$ complexes with several ligands, as $\operatorname{Ag}(\mathrm{I})$ with furosemide (MIC $=0.39 \mathrm{mmol} \mathrm{L}^{-1}$ for gram-positive bacteria strains) ${ }^{32}$, sulfathiazole (MIC $3.45 \mathrm{mmol} \mathrm{L}^{-1}$ for gram-negative bacteria and $6.90 \mathrm{mmol} \mathrm{L}^{-1}$ for Gram-positive bacteria strains) and sulfamethoxazole $\left(\mathrm{MIC}=1.74 \mathrm{mmol} \mathrm{L}^{-1}\right.$ for gram-negative bacteria and $13.9 \mathrm{mmol} \mathrm{L}^{-1}$ for gram-positive bacteria ${ }^{39}$. The results demonstrate the potential for using the $\left[\mathrm{Ag}_{2}\left(\mathrm{C}_{4} \mathrm{H}_{4} \mathrm{O}_{4}\right)\right]$ complex as an antibacterial drug in the future.

\subsection{Anti-Mycobacterium tuberculosis activity}

The $\mathrm{MIC}_{90}$ values for $\left[\mathrm{Ag}_{2}\left(\mathrm{C}_{4} \mathrm{H}_{4} \mathrm{O}_{4}\right)\right]$, succinic acid and rifampicin were obtained through REMA. Rifampicin, the most effective first-line drug, was used as a control and showed a $\mathrm{MIC}_{90}$ of $0.08 \mu \mathrm{g} \mathrm{mL}^{-1}$. The silver complex with succinate was shown to be active with a $\mathrm{MIC}_{90}$ of $23.94 \mu \mathrm{g} \mathrm{mL}^{-1}$ while succinic acid itself presented a value higher than $25.00 \mu \mathrm{g} \mathrm{mL}^{-1}$. In spite of being active, the $\left[\mathrm{Ag}_{2}\left(\mathrm{C}_{4} \mathrm{H}_{4} \mathrm{O}_{4}\right)\right]$ complex has a MIC value lower than that of other antimycobacterial agents used in TB clinical treatments as ethambutol
$\left(\mathrm{MIC}_{90}=5.62 \mu \mathrm{g} \mathrm{mL}^{-1}\right)$ and $p$-aminosalicylic $\left(\mathrm{MIC}_{90}=\right.$ $\left.1.25 \mu \mathrm{g} \mathrm{mL}^{-1}\right)$.

\section{Conclusions}

A new silver complex with succinic acid was obtained and characterized. On the basis of elemental and thermogravimetric analyses, the complex was formulated as $\left[\mathrm{Ag}_{2}\left(\mathrm{C}_{4} \mathrm{H}_{4} \mathrm{O}_{4}\right)\right]$. Infrared spectra showed that the value for $\Delta v$ decreases for both carboxylate groups because of the high symmetry of succinate anion compared to the free succinic acid molecule. The reduction of the $\Delta v$ value indicates coordination of each carboxylate group to each $\operatorname{Ag}(\mathrm{I})$ in a bidentate mode. The theoretical structures for succinic acid and the $\left[\mathrm{Ag}_{2}\left(\mathrm{C}_{4} \mathrm{H}_{4} \mathrm{O}_{4}\right)\right]$ complex were optimized to the minimum of energy using DFT. The studies confirm that each carboxylate group of the succinate coordinates to one $\mathrm{Ag}$ atom by the two $\mathrm{O}$ atoms in a bidentate mode as suggested by the IR data and the bond lengths $\mathrm{O} \cdots \mathrm{Ag}$ theoretically range from 2.325 to $2.338 \AA$.

The complex shows inhibitory activity against the considered strains used in the assay with MIC values $\leq$ $0.23 \mathrm{mmol} \mathrm{L}^{-1}$. Succinic acid, $\mathrm{K}^{+}$-succinate and DMSO aqueous solution were inactive. Anti-Mycobacterium tuberculosis analyses were also performed with $\left[\mathrm{Ag}_{2}\left(\mathrm{C}_{4} \mathrm{H}_{4} \mathrm{O}_{4}\right)\right]$ and succinic acid. The $\left[\mathrm{Ag}_{2}\left(\mathrm{C}_{4} \mathrm{H}_{4} \mathrm{O}_{4}\right)\right]$ complex was shown to be active presenting a $\mathrm{MIC}_{90}$ of $23.94 \mu \mathrm{g} \mathrm{mL}^{-1}$ while succinic acid itself presented a value higher than $25.00 \mu \mathrm{g} \mathrm{mL}^{-1}$. The results obtained indicate the significant activity in vitro of the silver complex with succinic acid and warrants for additional studies in the search of safer silver-based antimicrobial drugs.

\section{Acknowledgments}

This study was supported by grants from the Brazilian Agencies FAPESP (São Paulo State Research Council, Grants \#2018/12590-0, \#2017/11570-3 and 2018/12062-4), CNPq (National Council of Scientific and Technological Development, Grant \#300968/20167) and FUNADESP (National Foundation for the Development of Private Higher Education, Grant \#2700375). Douglas H. Pereira also acknowledges the 
Center for Computational Engineering and Sciences (Financial support from FAPESP, Grants \#2013/08293-7 and \#2017/11485-6) and the National Center for High Performance Processing (CENAPAD) in São Paulo for the computational resources. This study was partially financed by the Coordenação de Aperfeiçoamento de Pessoal de Nível Superior - Brasil (CAPES) - Finance Code 001.

\section{References}

[1] Zaman, S. B., Hussain, M. A., Nye, R., Mehta, V., Mamun, K. T., Hossain, N., A Review on Antibiotic Resistance: Alarm Bells are Ringing, Cureus 9 (6) (2017) e1403-e1403. https://doi.org/10.7759/cureus.1403.

[2] Silva, M., Aquino, S., Resistência aos antimicrobianos: uma revisão dos desafios na busca por novas alternativas de tratamento, Journal of Epidemiology and Infection Control 8 (4) (2018)

$472-482$. https://doi.org/10.17058/reci.v8i4.11580.

[3] World Health Organization (WHO), E. coli, World Health Organization, 2018. https://www.who.int/newsroom/fact-sheets/detail/e-coli.

[4] World Health Organization (WHO), Global tuberculosis report 2018, World Health Organization, 2018. https://apps.who.int/iris/handle/10665/274453.

[5] Cardoso, R. F., Cooksey, R. C., Morlock, G. P., Barco, P., Cecon, L., Forestiero, F., Leite, C. Q. F., Sato, D. N., Shikama, M. D., Mamizuka, E. M., Hirata, R. D. C., Hirata, M. H., Screening and characterization of mutations in isoniazid-resistant Mycobacterium tuberculosis isolates obtained in Brazil, Antimicrobial Agents and Chemotherapy $48 \quad$ (9) 3373-3381. https://doi.org/10.1128/aac.48.9.3373-3381.2004.

[6] Vaerewijck, M. J. M., Huys, G., Palomino, J. C., Swings, J., Portaels, F., Mycobacteria in drinking water distribution systems: ecology and significance for human health, Fems Microbiology Reviews 29 (5) (2005) 911-934. https://doi.org/10.1016/j.femsre.2005.02.001.

[7] Bernersprice, S. J., Johnson, R. K., Giovenella, A. J., Faucette, L. F., Mirabelli C. K., Sadler, P. J., Antimicrobial and anticancer activity of tetrahedral, chelated, diphosphine silver(I) complexes - comparison with copper and gold, Journal of Inorganic Biochemistry 33 (4) (1988) 285-295. https://doi.org/10.1016/0162-0134(88)80007-2.
[8] Gracia, C. G. de, An open study comparing topical silver sulfadiazine and topical silver sulfadiazine - cerium nitrate in the treatment of moderate and severe burns, Burns 27 (1) (2001) 67-74. https://doi.org/10.1016/s0305-4179(00)000619.

[9] Klasen, H. J., Historical review of the use of silver in the treatment of burns. I. Early uses, Burns 26 (2) (2000) 117 130. https://doi.org/10.1016/s0305-4179(99)00108-4.

[10] Nomiya, K., Yokoyama, H., Syntheses, crystal structures and antimicrobial activities of polymeric silver(I) complexes with three amino-acids aspartic acid (H2asp), glycine (Hgly) and asparagine (Hasn), Journal of the Chemical Society-Dalton Transactions (12) (2002) 24832490. https://doi.org/10.1039/b200684g.

[11] Nomiya, K., Kondoh, Y., Onoue, K., Kasuga, N. C., Nagano, H., Oda, M., Sudoh, T., Sakuma, S., Synthesis and characterization of polymeric, anionic thiosalicylato- $\mathrm{Ag}(\mathrm{I})$ complexes with antimicrobial activities, Journal of Inorganic $\begin{array}{lllll}\text { Biochemistry } & 58 & \text { (4) } & \text { (1995) }\end{array}$ https://doi.org/10.1016/0162-0134(94)00059-j.

[12] Matsumura, Y., Yoshikata, K., Kunisaki, S., Tsuchido, T., Mode of bactericidal action of silver zeolite and its comparison with that of silver nitrate, Appl Environ $\begin{array}{lllll}\text { Microbiol } & 69 & \text { (7) } & \text { (2003) 4278-4281. }\end{array}$ https://doi.org/10.1128/aem.69.7.4278-4281.2003.

[13] Feng, Q., Wu, J., Chen, G.-Q., Cui, F.-Z., Kim, T., Kim, J., A mechanistic study of the antibacterial effect of silver ions on Escherichia coli and Staphylococcus aureus, Journal of Biomedical Materials Research 52 (4) (2000) 662-668. https://doi.org/10.1002/1097-4636(20001215)52:43.0.CO;23.

[14] Liau, S. Y., Read, D. C., Pugh, W., Furr, J. R., Russell, A. D., Interaction of silver nitrate with readily identifiable groups: relationship to the antibacterial action of silver ions, Letters in Applied Microbiology 25 (4) (2003) 279-283. https://doi.org/10.1046/j.1472-765X.1997.00219.x.

[15] Russell, A. D., Hugo, W. B., 7 Antimicrobial activity and action of silver, In: Progress in Medicinal Chemistry, Ellis, G. P., Luscombe, D. K., eds., Elsevier, 1994. https://doi.org/10.1016/S0079-6468(08)70024-9.

[16] Nomiya K., Noguchi, R., Oda, M., Synthesis and crystal structure of coinage metal(I) complexes with tetrazole (Htetz) and triphenylphosphine ligands, and their antimicrobial activities. A helical polymer of silver(I) 
complex $[\mathrm{Ag}($ tetz $)(\mathrm{PPh} 3) 2] \mathrm{n}$ and a monomeric gold(I) complex [Au(tetz)(PPh3)], Inorganica Chimica Acta 298 (1) (2000) 24-32. https://doi.org/10.1016/s0020-1693(99)004016.

[17] Nomiya, K., Noguchi, R., Shigeta, T., Kondoh, Y., Tsuda, K., Ohsawa, K., Chikaraishi-Kasuga, N., Oda, M., Synthesis and structural characterization of silver(I) and gold(I) complexes with 2-mercaptonicotinic acid (H2mna) and triphenylphosphine ligands, and their antimicrobial activities. Crystal structures of monomeric, 3-and 4coordinate silver(I) complexes [Ag(Hmna)(PPh3)2]and $[\mathrm{Ag}(\mathrm{Hmna})(\mathrm{PPh} 3) 3]$ in the solid state, Bulletin of the Chemical Society of Japan 73 (5) (2000) 1143-1152. https://doi.org/10.1246/bcsj.73.1143.

[18] Cornils, B., Lappe, P., Dicarboxylic Acids, Aliphatic, Ullmann's Encyclopedia of Industrial Chemistry (2000). https://doi.org/10.1002/14356007.a08_523.

[19] Shabanova, I. V., Frolov, V. Y., Storozhenko, T. P., Zelenov, V. I., Heterometallic Nd(III) and Fe(III) Complexes with succinic acid and its derivative: synthesis and physicochemical properties, Russian Journal of Coordination $\begin{array}{llll}\text { Chemistry } & 31 & \text { (2005) }\end{array}$ https://doi.org/10.1007/s11173-005-0107-1.

[20] Sladkov, V., Bessonov, A. A., Roques, J., Charushnikova, I. A., Fedosseev, A. M., Complexation of $\mathrm{An}(\mathrm{VI})$ with succinic acid in aqueous acid solutions: uranyl vs. plutonyl, New Journal of Chemistry 42 (10) (2018) 77807788. https://doi.org/10.1039/C7NJ04061J.

[21] Pereira, A. K. dos S., Manzano, C. M., Nakahata, D.H., Clavijo, J. C. T., Pereira, D. H., Lustri, W. R., Corbi, P. P., Synthesis, crystal structures, DFT studies, antibacterial assays and interaction assessments with biomolecules of new platinum(ii) complexes with adamantane derivatives, New Journal of Chemistry $27 \quad$ (2020) https://doi.org/10.1039/D0NJ02009E.

[22] Becke, A. D., Density-functional thermochemistry. III. The role of exact exchange, The Journal of Chemical $\begin{array}{lllll}\text { Physics } & 98 & \text { (7) } & \text { (1993) }\end{array}$ https://doi.org/10.1063/1.464913.

[23] Lee, C., Yang, W., Parr, R. G., Development of the Colle-Salvetti correlation-energy formula into a functional of the electron density, Physical Review B. 37 (1988) 785-789. https://doi.org/10.1103/PhysRevB.37.785.
[24] Vosko, S. H., Wilk, L., Nusair, M., Accurate spindependent electron liquid correlation energies for local spin density calculations: a critical analysis, Canadian Journal of $\begin{array}{lllll}\text { Physics } & 58 & \text { (8) } & \text { (1980) }\end{array}$ https://doi.org/10.1139/p80-159.

[25] Ditchfield, R., Hehre, W. J., Pople, J. A., Self-Consistent Molecular-Orbital Methods. IX. An Extended Gaussian-Type Basis for Molecular-Orbital Studies of Organic Molecules, The Journal of Chemical $\begin{array}{lllll}\text { Physics } & 54 & \text { (2) } & \text { (1971) }\end{array}$ https://doi.org/10.1063/1.1674902.

[26] Hehre, W. J., Ditchfield, R., Pople, J. A., SelfConsistent Molecular Orbital Methods. XII. Further Extensions of Gaussian-Type Basis Sets for Use in Molecular Orbital Studies of Organic Molecules, The Journal of Chemical Physics 56 (5) (1972) 2257-2261. https://doi.org/10.1063/1.1677527.

[27] Hariharan, P. C., Pople, J. A., The influence of polarization functions on molecular orbital hydrogenation energies, Theoretica Chimica Acta 28 (1973) 213-222. https://doi.org/10.1007/BF00533485.

[28] Hay, P. J., Wadt, W.R., Ab initio effective core potentials for molecular calculations. Potentials for the transition metal atoms $\mathrm{Sc}$ to $\mathrm{Hg}$, The Journal of Chemical $\begin{array}{lllll}\text { Physics } & 82 & \text { (1) 270-283. }\end{array}$ https://doi.org/10.1063/1.448799.

[29] Frisch, J., Trucks, G. W., Schlegel, H. B., Scuseria, G. E., Robb, M. A., Cheeseman, J. R., Scalmani, G., Barone, V., Mennucci, B., Petersson, G. A., Nakatsuji, H., Caricato, M., Li, X., Hratchian, H. P., Izmaylov, A. F., Bloino, J., Zheng, G., Sonnenberg, J. L., Hada, M., Ehara, M., Toyota, K., Fukuda, R., Hasegawa, J., Ishida, M., Nakajima, T., Honda, Y., Kitao, O., Nakai, H., Vreven, T., Montgomery, J. A., Peralta, J. E., Ogliaro, F., Bearpark, M., Heyd, J. J., Brothers, E., Kudin, K. N., Staroverov, V. N., Kobayashi, R., Normand, J., Raghavachari, K., Rendell, A., Burant, J. C., Iyengar, S. S., Tomasi, S., Cossi, M., Rega, N., Millam, J. M., Klene, M., Knox, J. E., Cross, J. B., Bakken, V., Adamo, C., Jaramillo, J., Gomperts, R., Stratmann, R. E., Yazyev, O., Austin, A. J., Cammi, R., Pomelli, C., Ochterski, J. W., Martin, R. L., Morokuma, K., Zakrzewski, V. G., Voth, G. A., Salvador, P., Dannenberg, J. J., Dapprich, S., Daniels, A. D., Farkas, Ö., Foresman, J. B., Ortiz, J. V., Cioslowski, J., Fox, D.J., Gaussian09, Revision D.1, Semichem Inc., Shawnee Mission, 2009. 
[30] Dennington, R., Keith, T., Millam, J., Gauss View, Semichemical Inch., Shawnee Mission, 2009.

[31] Clinical and Laboratory Standards Institute (CLSI), Performance Standards for Antimicrobial Susceptibility Testing, 26th ed., Clinical and Laboratory Standards Institute, Wayne, Pennsylvania, USA, 2016.

[32] Lustri, W. R., Lazarini, S. C., Lustri, B. C., Corbi, P. P., Silva, M. A. C., Nogueira, F. A. R., Aquino, R., Amaral, A. C., Treu Filho, O., Massabni, A. C., Barud, H. da S., Spectroscopic characterization and biological studies in vitro of a new silver complex with furosemide: Prospective of application as an antimicrobial agent, Journal of Molecular Structure $\quad 1134 \quad$ (2017) 386-394. https://doi.org/10.1016/j.molstruc.2016.12.056.

[33] Palomino, J.-C., Martin, A., Camacho, M., Guerra, H., Swings, J., Portaels, F., Resazurin microtiter assay plate: simple and inexpensive method for detection of drug resistance in Mycobacterium tuberculosis, Antimicrobial Agents and ChemotheraPY 46 (8) (2002) 2720-2722. https://doi.org/10.1128/AAC.46.8.2720-2722.2002.

[34] Nelson, J. H., A Review of: "Metal Carboxalates. R.C. Mehrotra and R. Bohra, Academic Press, New York, 1983. VIII + 396 pp.," Synthesis and Reactivity in Inorganic and Metal-Organic Chemistry 14 (3) (1984) 441-442. https://doi.org/10.1080/00945718408055903.

[35] Colthup, N. B., Daly, L. H., Wiberley, S. E., Carbonyl compounds, In: Introduction to Infrared and Raman Spectroscopy (Third Edition), Colthup, N. B., Daly, L. H., Wiberley, S. E., eds., Academic Press: San Diego, California, 1990, Ch 9. https://doi.org/10.1016/B978-0-08091740-5.50012-0.

[36] Sun, D., Liu, F.-J., Hao, H.-J., Li, Y.-H., Huang, R.-B., Zheng, L.-S., Six low-dimensional silver(I) coordination complexes derived from 2-aminobenzonitrile and carboxylates, Inorganica Chimica Acta 387 (2012) 271-276. https://doi.org/10.1016/j.ica.2012.01.027.

[37] Castellano, J. J., Shafii, S. M., Ko, F., Donate, G., Wright, T. E., Mannari, R. J., Payne, W. G., Smith, D. J., Robson, M. C., Comparative evaluation of silver-containing antimicrobial dressings and drugs, International Wound Journal 4 (2) (2007) 114-122. https://doi.org/10.1111/j.1742481X.2007.00316.x.

[38] Fox Júnior., C. L., Modak, S. M., Mechanism of silver sulfadiazine action on burn wound infections, Antimicrobial
Agents and Chemotherapy 5 (6) (1974) 582-588. https://doi.org/10.1128/AAC.5.6.582.

[39] Nunes, J. H. B., Paiva, R. E. F. de, Cuin, A., Lustri, W. R., Corbi, P. P., Silver complexes with sulfathiazole and sulfamethoxazole: Synthesis, spectroscopic characterization, crystal structure and antibacterial assays, Polyhedron 85 (2015) 437-444. https://doi.org/10.1016/j.poly.2014.09.010. 